\title{
Performance of insecticides in control of Diatraea saccharalis (Lepidoptera: Crambidae) in sugarcane
}

\section{Desempenho de inseticidas no controle de Diatraea saccharalis (Lepidoptera: Crambidae) em cana-de-açúcar}

\author{
Marcelo Feitosa da Silva' (1D) (https://orcid.org/0000-0002-3081-1029) \\ Marina Funichello 2 (1) (https://orcid.org/0000-0003-4734-0945) \\ Diego Miranda de Souza ${ }^{*}$ (1) (https://orcid.org/0000-0002-4965-713X)
}

\begin{abstract}
The population of the caterpillar Diatraea saccharalis (Lepidoptera: Crambidae) has increased in the crop of sugarcane in recent years. Although the control of this insect is traditionally carried out through biological control, the use of phytosanitary products has still been necessary. Therefore, the goal of this work was to evaluate the performance of different insecticides in sugarcane borer control, as well as the effect on productivity and total recoverable sugar (TRS). The experiment was conducted in a randomized experimental delineation of blocks, with six treatments and four blocks. Treatments consisted of five insecticides and one control group (without application of insecticide). For calculating the $D$. saccharalis infestation index, monthly samplings were performed every 30 days, for 12 months. After this period, the final $D$. saccharalis infestation index was evaluated and calculated for each treatment. In order to compare productivity among procedures, four central lines were collected from each plot. Thus, the samples were weighed for the productivity calculation (TCH) and sent to the laboratory for the total recoverable sugar (TRS) analysis. The chloranthraniliprole (350) insecticide provided a lower index of sugarcane borer infestation, in addition to greater productivity when compared to the other insecticides. There was no significant difference in the parameter of total recoverable sugar (TRS) among treatments.
\end{abstract}

KEYWORDS: sugarcane borer; chemical control; pest management.
RESUMO: A população da lagarta Diatraea saccharalis (Lepidoptera: Crambidae) tem aumentado na cultura de cana-de-açúcar nos últimos anos. Apesar do controle deste inseto ser tradicionalmente realizado através do controle biológico, o uso de produtos fitossanitários ainda tem sido necessário. Portanto, o objetivo deste trabalho foi avaliar o desempenho de diferentes inseticidas no controle da broca da canade-açúcar, bem como o efeito sobre a produtividade e o açúcar total recuperável (ATR). O experimento foi conduzido no delineamento experimental de blocos ao acaso, com seis tratamentos e quatro blocos. Os tratamentos foram compostos por cinco inseticidas e um tratamento sem aplicação de inseticida. Para o cálculo do índice de infestação da $D$. saccharalis foram realizadas amostragens mensais a cada 30 dias, durante 12 meses. Após esse período, foi avaliado e calculado o índice de infestação final da $D$. saccharalis de cada tratamento. Para comparar a produtividade entre os tratamentos, foram colhidas as quatro linhas centrais de cada parcela. Assim, as amostras foram pesadas para o cálculo da produtividade (TCH) e enviadas ao laboratório para análise do açúcar total recuperável (ATR). O inseticida clorantraniliprole (350) proporcionou um menor índice de infestação da broca da cana, além de maior produtividade, em relação aos demais inseticidas. Não houve diferença significativa do parâmetro de açúcar total recuperável (ATR) entre os tratamentos.

PALAVRAS-CHAVE: broca da cana-de-açúcar; controle-químico; manejo de pragas. 


\section{INTRODUCTION}

Sugarcane (Saccharum officinarum L.) is a monocot, typical of tropical and subtropical climates, originally from Southeast Asia (JAMES, 2004). It has historical importance in Brazil's formation, since it was the first botanical species of economic expression introduced and cultivated on the northeast coast. Due to the production of ethyl alcohol and sugar, this grass was disseminated in almost all Brazilian states, establishing itself in the most diverse edaphoclimatic conditions (MARIN; NASSIF, 2013; UNICA, 2017).

Global demand for biofuels has stimulated national ethanol production; thus, the sugar and alcohol sector in Brazil has increased sugarcane production (BARBOSA; GATTI JÚNIOR, 2012). An estimate of the area planted for the 2017 harvest in the country reached 8.73 million hectares and a production of around 637.31 million tons of sugar cane (CONAB, 2016).

However, the crop suffers from agents that can reduce the plantation productivity over the cycle, including the caterpillar Diatraea saccharalis F. (Lepidoptera: Crambidae), sugarcane borer, that is considered a pest insect of great importance in the crop due to the damage it can cause.

The damage caused by the borer can be direct, such as breaking of stalks and even the death of younger plants. The death of young plants can occur from the symptom known as "dead heart", caused by the destruction of the apical meristem (BOTELHO; MACEDO, 2002; GALLO et al., 2002; DINARDO-MIRANDA, 2008), or it can also cause indirect damage, by allowing fungi entry that cause the red rot disease in the stalk, which causes loss of production quality and sugar content in plants (GALLO et al., 2002; SEGATO et al., 2006).

Regarding the biological cycle of the pest, the caterpillars hatch after 4 to 9 days of moth laying and start to feed on the parenchyma of the leaves. They remain outside the stalk for about 7 to 15 days. Afterwards, they go down the leaf and penetrate the stalk.

The galleries open inside the stalk and about 40 days after entry, the caterpillars open an exit hole and close it with silk threads and sawdust, passing to a pupal stage. About 10 days later, the pupa turns into a moth, leaves through the open hole, restarting a new cycle (DINARDO-MIRANDA, 2008; COSTA et al., 2010; SANDOVAL; SENÔ, 2010).

The sampling process of pest insects is essential to reveal the appropriate time of control. In sugarcane, an estimate of sugarcane borer infestation is performed by collecting and opening stalks longitudinally. This data collection helps to identify areas that require greater attention in the management of pest insects for the next harvest (GALLO et al., 2002; PINTO, 2006).

Despite the widespread adoption of biological control in the management of sugarcane borer, chemical control has been adopted to keep the pest population below the level of economic damage. Insecticides must be applied to the first two larval instars, trying to prevent the caterpillars from penetrating the inside of the stalk (CRUZ, 2007; ERLER, 2010).

Currently, even considering biological control, there are only 49 phytosanitary products registered for the management of this insect in the sugarcane cultivation. Consequently, options for insecticidal chemical groups available to the sugarcane producer are scarce (AGROFIT, 2018).

Therefore, the goal of this work was to evaluate the performance of different insecticides in the control of sugarcane borer, as well as the effect on the productivity and total recoverable sugar (TRS).

\section{MATERIAL AND METHODS}

The present work was carried out at Lineu farm, located in Rancharia municipality, in São Paulo State. During the period of the experiment, due to the lease contract, the area was under the responsibility of Cocal Plant.

Planting was done in $01 / 24 / 2016$, with no spacing between lines of $1.5 \mathrm{~m}$. The variety of sugarcane used was the RB867515. The main agronomic characteristics of RB867515 are high growth speed, high height, erect growing habit, high stalk density, purplish green color and easy straw removal, drought tolerant, good ratooning, high sucrose content, fast growth with high productivity.

The materials required for the installation of the experiment were: machete, measuring tape and bamboo poles to mark treatments and identification tags. The experiment was installed on $03 / 12 / 2016$, from the pathways opening to the selection of 24 experimental plots. The plots were identified with tags affixed to bamboo poles. The borders around the whole experiment were considered in order to protect and reduce the external variation.

Each plot was composed of 8 lines of $10 \mathrm{~m}$ of length each. The internal pathways were kept at $2 \mathrm{~m}$ and the last one at $3 \mathrm{~m}$, identifying the end of the experiment. The application of insecticides was performed on 03/19/2016, after the installation of the experiment in the field, in order to optimize activities.

The experiment was conducted in a randomized experimental delineation of blocks, with six treatments and four blocks. The procedures consisted of five insecticides (novaluron, triflumuron, chloranthraniliprole (100), chloranthraniliprole (350), tiametoxan + lambda-cyhalothrin), and a control group (without application of any insecticide) (see Table 1).

The insecticides were applied with a backpack sprayer, powered by $\mathrm{CO}_{2}$. The equipment has a bar with six nozzles, spaced at $0.5 \mathrm{~m}, 11002 \mathrm{AG}$ model spray tip, and calibrated with a working pressure of $2 \mathrm{kgf} / \mathrm{cm}^{2}$. The application was carried out with personal protective equipment (PPE).

Data on the weather at the time of application was obtained by the weather station at Cocal plant (temperature: $25^{\circ} \mathrm{C}\left(77^{\circ} \mathrm{F}\right)$; 
relative humidity: $80 \%$; wind speed $7 \mathrm{~km} / \mathrm{h}$ ). The application took place in the morning, from 6:30 to 7:30 a.m.

The sugarcane borer monitoring was carried out every 30 days. Notes were taken on the sugarcane external and internal stalk borer. Ten canes were evaluated per plot, 5 canes at the second street and 5 canes at the seventh street, for a total of 40 canes evaluated per treatment. The insects on the outside were carefully monitored, removing a stalk straw and taking notes on the number of borers on them. The collected data were used to calculate the infestation index. In order to evaluate the insects, present in the internal part, the stalks were removed and longitudinally cut. Data were presented in the form of borers per hectare.

After 12 months, the final infestation of $D$. saccharalis was evaluated, and the insect pest infestation index for each treatment was calculated. Ten canes were randomly collected by plots, 5 canes at third street and 5 canes at sixth street. For the calculation of the infestation index, the counting of the bored internodes was performed and divided by the total number of internodes sampled (GALLO et al., 2002; DINARDO-MIRANDA, 2008; DINARDO-MIRANDA et al., 2013).

In order to compare the productivity among the procedures, four central lines were collected from each plot. Thus, the samples were weighed to calculate the productivity (TCH) and sent to the laboratory for the total recoverable sugar (TRS) analysis.
The productivity evaluation of the treatments was carried out on 19/03/2017, for later calculation of the quantity of cane ton per hectare $(\mathrm{TCH})$ and the TRS, per treatment. Lines 4 and 5 were sampled, which were not used in other analysis throughout the experiment. In other words, no stalk was removed during the following 12 months in these lines.

For TRS evaluation, samples of each plot were identified and sent to the laboratory of sugarcane payment according to the sucrose content (SPLSC), located at the unit of Cocal plant in Paraguaçu Paulista city, São Paulo State. In the laboratory, the methods described in the Consecana's instruction manual were used (CONSECANA, 2006). Data were submitted to variance analysis and later to the mean test (Tukey's - 5\%), using SASM-Agri, a statistical software (CANTERI, 2001).

\section{RESULTS AND DISCUSSION}

The higher indexes of sugarcane borer present at the external part of the stalk (observed in March) reached around 12\% (Fig. 1), which is higher than the recommended 3\% control level (GALLO et al., 2002). However, in the following months, after the application of the insecticides, the insect population was abruptly reduced (Fig. 1). Besides the effect of the insecticide on the pest, it is also necessary to highlight that there was a period of water shortage, typical for the region. Humidity plays

Table 1. Treatments in the experiment.

\begin{tabular}{lccc} 
Commercial name & Chemical group & Active ingredient & Dose/ha \\
\hline 1 - Control & ---- & $-\cdots$ & --- \\
\hline 2 - Rimon & Benzoylurea & Novaluron & $150 \mathrm{~mL}$ \\
\hline $3-$ Certero & Benzoylurea & Triflumuron & $80 \mathrm{~mL}$ \\
\hline $4-$ Ampligo & Anthranilamide & Chloranthraniliprole (100) & $100 \mathrm{~mL}$ \\
\hline 5 - Altacor & Anthranilamide & Chloranthraniliprole (350) & $60 \mathrm{~g}$ \\
\hline 6 - Engeo Pleno & Neonicotinoid + Pyrethorid & Tiametoxan + lambda-cyhalothrin & $150 \mathrm{~mL}$ \\
\hline
\end{tabular}

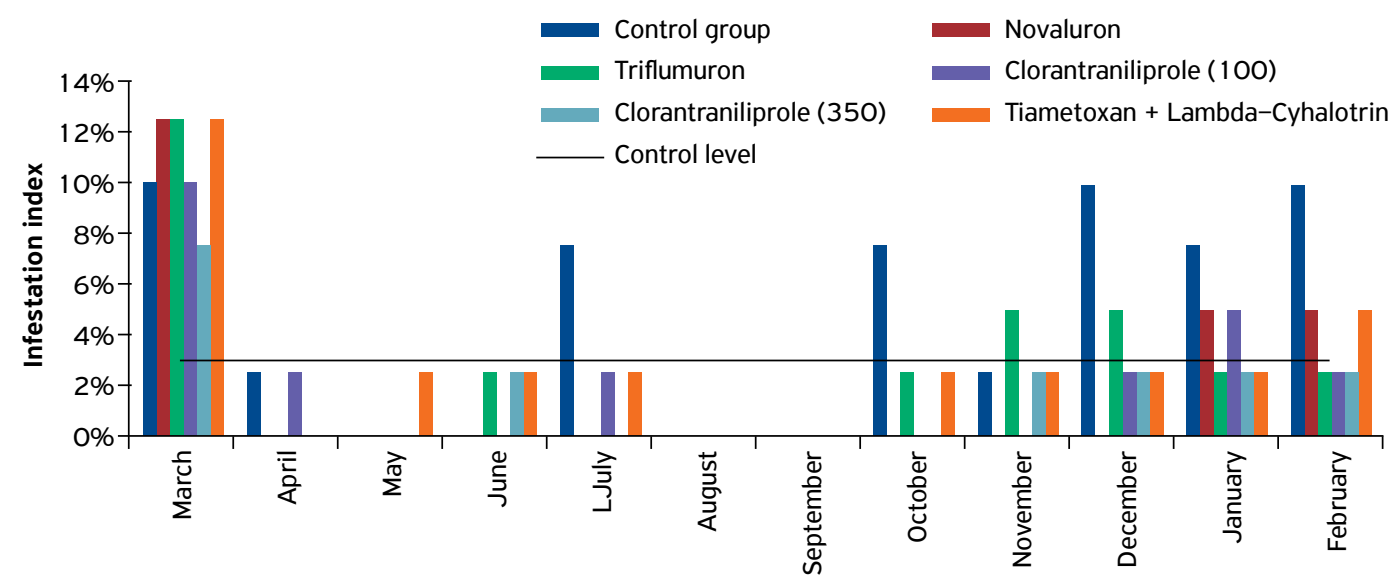

Figure 1. Infestation index of sugarcane borer in the external part of stalks over the months of the year. 
a main role in the insect pest cycle, so that, in droughts, the borer increases the duration of pupal stage, thus reducing the presence of insects in the external part of the stalks (GALLO et al., 2002; DINARDO-MIRANDA, 2008).

From October on, the borer population started to grow once again, exceeding the $3 \%$ index in practically every month up to the harvest. The insecticide treatments showed to be efficient in the reduction of the borer infestation index in relation to the plots that did not received the application. Treatments that used the chloranthraniliprole as the active ingredient did not allow the insect population to exceed the 3\% index (Fig. 1).

Monthly evaluations of the presence of borer in the internal part of the stalk are presented in number of borers per hectare (Fig. 2). It is possible to note that the number of borers per hectare before the application was around 10,000 individuals. However, in the following months, this population was reduced due to the application of insecticides. According to PINTO et al. (2006), the release of the Cotesia flavipes biological control must be initiated when the population reaches from 800 to 1000 caterpillars per hectare.

Differently from the observed during the monitoring of the external part of stalks, the insect was present in the interior of the stalk throughout all the evaluation period, independently of the weather conditions.

Diatraea saccharalis presents holometabolism. In other words, the insect goes through the egg, maggot, pupa, and adult phases. The duration of the biological cycle is highly variable and depends on several factors, mainly the weather and the host plant (LOPES, 2012).

According to PINTO (2006), the sugarcane planted in the beginning of the year (one-year-and-a-half sugarcane) is more frequently attacked by the borer during the summer, while for the one-year sugarcane, planted from September to October, the attack is more intense during the winter, at least in the São Paulo State. The planting of the experiment was done in January, but it is possible to observe an intense attack even in the winter (Fig. 2). The fluctuation of the population of a pest and its relationship with weather factors can be very different from one region to another. An important factor in a region may not play the same role in another one. Thus, the pest population dynamic is specific of the crop growing place (PORTELA et al., 2010).

Table 2 shows the final index of borer infestation. Data analysis shows there was a significant difference among treatments, with the chloranthraniliprole (350) insecticide presenting better performance in the control of caterpillars with a lower final index of borer infestation (2.40\%) significantly different from the control group, which reached $16.40 \%$ of final index of borer infestation.

Novaluron and triflumuron belong to the group of insecticides known as growth regulators, from the chemical group benzoylurea. They act by inhibiting the chitin synthesis of the pest insect during the bud phase, preventing the ecdysis process. This group of insecticides act only after the ingestion of the insecticide by the insect (IRAC, 2017). It is possible that this way of action may have impacted this insecticide efficacy, given that a good distribution of the product on the sugarcane leaves is vital.

On the other hand, the chloranthraniliprole insecticide, from the anthranilamide chemical group, acts on the modulators

Table 2. Final index of sugarcane borer infestation (FII).

\begin{tabular}{lcc}
\hline Treatment & Dose/ha & FII (\%) \\
\hline 1 - Control & - & $16.40 \mathrm{c}$ \\
\hline 2 - Novaluron & $150 \mathrm{~mL}$ & $10.54 \mathrm{bc}$ \\
\hline 3 - Triflumuron & $80 \mathrm{~mL}$ & $9.03 \mathrm{bc}$ \\
\hline 4 - Chloranthraniliprole (100) & $100 \mathrm{~mL}$ & $6.01 \mathrm{ab}$ \\
\hline 5 - Chloranthraniliprole (350) & $60 \mathrm{~g}$ & $2.40 \mathrm{a}$ \\
\hline $\begin{array}{l}\text { 6 - Tiametoxan + lambda- } \\
\text { cyhalothrin }\end{array}$ & $150 \mathrm{~mL}$ & $4.41 \mathrm{abc}$ \\
\hline CV (\%) & & 42.47 \\
\hline
\end{tabular}

Averages followed by different letters are different in the $5 \%$ level of probability, according to the Tukey's test.

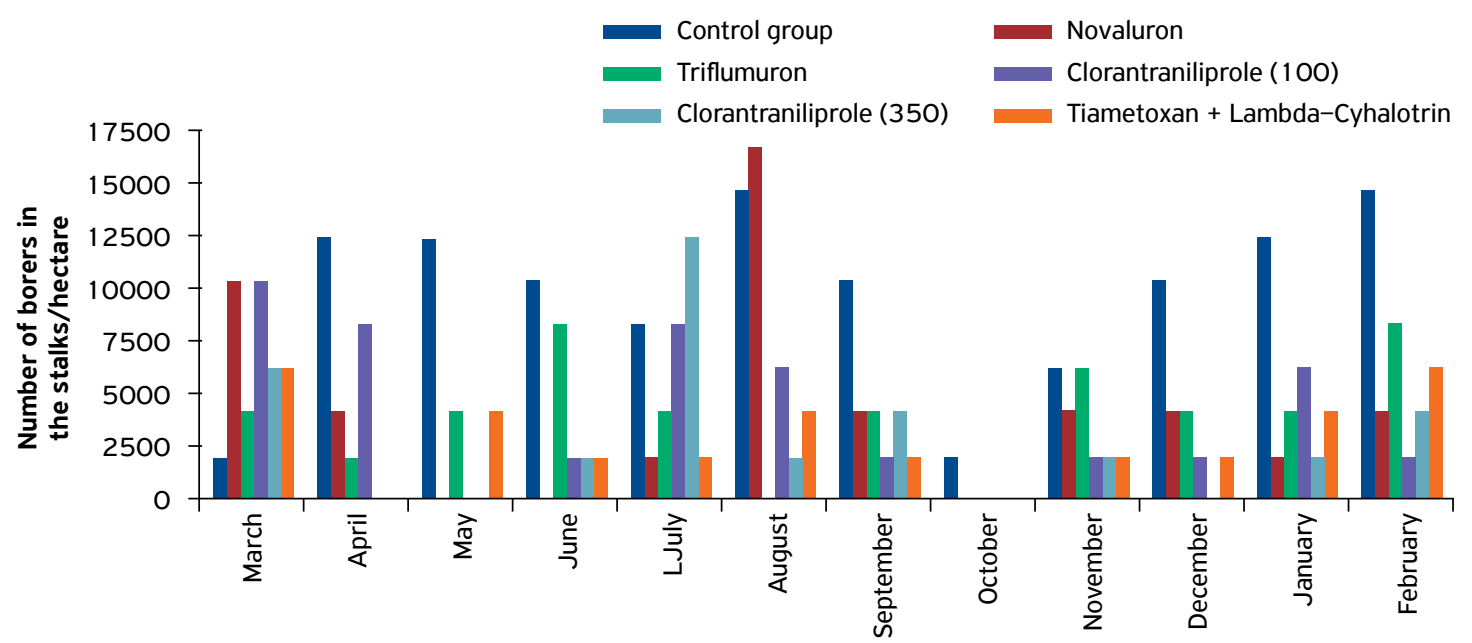

Figure 2. Sugarcane borer monitored on the internal part of stalks, per hectare, over months of the year. 
of ryanodine receptors. In other words, it allows the insect pest to have a rapid increase in calcium concentration in the muscles, causing a total paralysis of the insect pest after the contact and even ingestion, thus increasing the chances of borer control, according to the results observed (Table 2). Another advantage of the molecule is that the anthranilic diamides present low toxicity to mammals, birds and fishes; therefore, it does not present risks to nontarget organisms (CAMPOS et al., 2011).

Table 3 depicts the production by treatment, in tons of sugarcane per hectare (TSH). It is possible to observe that there was significant difference among treatments. Chloranthraniliprole (100) and chloranthraniliprole (350) treated plots presented the best performances, with a productivity of 110.24 and 82.80 tons of sugarcane by hectare respectively, significant differing from the control group, with a productivity of 55.85 tons of sugarcane per hectare.

For every $1 \%$ of sugarcane borer infestation, there is a reduction of $0.77 \%$ on sugarcane productivity, $0.25 \%$ on sugar and $0.20 \%$ on ethanol productions (ARRIGONI, 2002. Regarding the TRS, there was no significant difference among treatments. On the other hand, it can be observed that, when the chloranthraniliprole (350) insecticide is applied, there is an increase of $1.19 \mathrm{~kg}$ of sugar in comparison to the control group, where no insecticide was applied (Table 4).

When relating TCH and TRS, in only one hectare, chloranthraniliprole (350) allowed 12,799.97 kg of sugar, while the control group, on average, allowed only $6,418.28 \mathrm{~kg}$ of sugar per hectare. Analyzing these values in Brazilian real, according to CONSECANA (2017), the price of one kg of sugar was $R \$ 0.575$. Thus, when calculating the sugar production in the presence of chloranthraniliprole (350) insecticide, it is possible to earn $\mathrm{R} \$ 7,366.40$, almost twice as much as the value earned from the control group, $\mathrm{R} \$ 3,693.70$.

The presence of sugarcane borer may allow the colonization of several microorganisms, specially fungi, which cause the "red rot disease" (BOTELHO, 1992). Although not evaluated, it is probable that the sucrose inversion allowed by these microorganisms may have impacted the final sugar production.
Table 3. Tons of sugarcane per hectare (TSH).

\begin{tabular}{lcc}
\hline Treatments & Dose/ha & TSH (ton/ha) \\
\hline 1 - Control & -- & $55.85 \mathrm{c}$ \\
\hline 2 - Novaluron & $150 \mathrm{~mL}$ & $69.50 \mathrm{bc}$ \\
\hline 3 - Triflumuron & $80 \mathrm{~mL}$ & $56.85 \mathrm{c}$ \\
\hline 4 - Chloranthraniliprole (100) & $100 \mathrm{~mL}$ & $82.80 \mathrm{~b}$ \\
\hline 5 - Chloranthraniliprole (350) & $60 \mathrm{~g}$ & $110.24 \mathrm{a}$ \\
\hline $\begin{array}{l}\text { 6 - Tiametoxan + Lambda- } \\
\text { Cyhalothrin }\end{array}$ & $150 \mathrm{~mL}$ & $65.82 \mathrm{c}$ \\
\hline CV (\%) & & 12.54 \\
\hline
\end{tabular}

Averages followed by different letters are different in the $5 \%$ level of probability, according to the Tukey's test.

Table 4. Total recoverable sugar (TRS) kg/ton/sugarcane.

\begin{tabular}{lcc|}
\hline Treatments & Dose/ha & TRS \\
\hline 1 - Control & - & $114.92 \mathrm{a}$ \\
\hline 2 - Novaluron & $150 \mathrm{~mL}$ & $113.07 \mathrm{a}$ \\
\hline 3 - Triflumuron & $80 \mathrm{~mL}$ & $113.20 \mathrm{a}$ \\
\hline 4 - Chloranthraniliprole (100) & $100 \mathrm{~mL}$ & $114.90 \mathrm{a}$ \\
\hline 5 - Chloranthraniliprole (350) & $60 \mathrm{~g}$ & $116.11 \mathrm{a}$ \\
\hline $\begin{array}{l}\text { 6 - Tiametoxan + Lambda- } \\
\text { Cyhalothrin }\end{array}$ & $150 \mathrm{~mL}$ & $115.94 \mathrm{a}$ \\
\hline CV (\%) & & 7.32 \\
\hline
\end{tabular}

Averages followed by different letters are different in the 5\% probability level, according to the Tukey's test.

\section{CONCLUSIONS}

Insecticides allowed reduction in the infestation index of sugarcane borer and allowed an increase in the crop productivity. The chloranthraniliprole (350) insecticide allowed a lower infestation index of sugarcane borer, besides higher productivity, in comparison to the other insecticides. There were no significant differences on the TRS parameter among treatments.

ACKNOWLEDGEMENTS: The authors would like to thank the company COCAL for the support in the experiment.

FUNDING: This work did not receive any specific grant from funding agencies in the public, commercial, or not-for-profit sectors.

CONFLICTS OF INTEREST: All authors declare that they have no conflict of interest.

ETHICAL APPROVAL: Not applicable.

AUTHORS' CONTRIBUTIONS: Conceptualization: Silva, M.F. Data curation: Silva, M.F. Formal analysis: Silva, M.F. Investigation: Silva, M.F. Methodology: Funichello, M. Project administration: Funichello, M. Resources: Silva, M.F. Supervision: Souza, D.M. Validation: Souza, D.M. Visualization: Souza, D.M. Writing - original draft: Silva, M.F.; Souza, D.M. Writing - review \& editing: Souza, D.M. 
| | | | | | | | | | | | | | | | | | | | | | | | | | | | | | | | | | | | | | | | | | | | | | | | | | | | | | | | | | | | | | | | | | | | | | | | | | | | | | | | | | | | | | | | | | | | | | | | | | | | | | | | | | | | | | | | | | | | | | | | | | | | | | | | | | | | | | | | | | | | | | | | | | | | | | | | | | | | | | | | | | | | | | | | | | | | | | | | | | | | | | | | | | | | | | | | | | | | | | | | | | | | REFERENCES

AGROFIT. Sistema de agrotóxicos fitossanitários, do Ministério da Agricultura, Pecuária e Abastecimento. 2018. Available from: http:// agrofit.agricultura.gov.br/agrofit_cons/principal_agrofit_cons. Access on: 22 Feb. 2018.

ARRIGONI, E.B. Broca da cana-de-açúcar: Importância econômica e situação atual. In: ARRIGONI, E.B.; DINARDO-MIRANDA, L.L.; ROSSETO, R. (ed). Pragas da cana-de-açúcar: importância econômica e enfoques atuais. Piracicaba: STAB/IAC/CTC, 2002.

BARBOSA, A.P.F.P.L.; GATTI JUNIOR, W. Cenários tecnológicos para a demanda por cana de açúcar. Future Studies Research Journal: Trends and Strategies, São Paulo, v.4, n. 1, p.92-1 13, 2012. https:// doi.org/10.24023/FutureJournal/2175-5825/2012.v4i 1.94

BOTELHO, P.S.M. Quinze anos de controle biológico da Diatraea saccharalis utilizando parasitoides. Pesquisa Agropecuária Brasileira, Brasília, v.27, p.255-262, 1992. Available from: https://ainfo. cnptia.embrapa.br/digital/bitstream/AI-SEDE/20659/1/ pab21_abresp_92.pdf. Access on: 13 Jun. 2018.

BOTELHO, P.S.M; MACEDO, N. Descrição e bioecologia de $D$. saccharalis. In: PARRA, J.R.P.; BOTELHO, P.S.M.; CORRÊA-FERREIRA B.S.; BENTO, J.M.S. Controle Biológico no Brasil: parasitóides e predadores. São Paulo: Manole, 2002. chap.25, p.411-412.

CAMPOS, M.R.; PICANÇO, M.C.; MARTINS, J.C.; TOMAZ, A.C.; GUEDES, R.N.C. Insecticide selectivity and behavioral response of the earwig Doru luteipes. Crop Protection, Lincoln, v.30, n. 12, p.15351540, 2011 . https://doi.org/10.1016/j.cropro.2011.08.013

CANTERI, M.G.; Althaus R.A.; VIRGENS FILHO, J.S.; GIGLIOTI, É.A.; GODOY, C.V. SASM-Agri - Sistema para análise e separação de médias em experimentos agrícolas pelos métodos Scott-Knott, Tukey e Duncan. Revista Brasileira de Agrocomputação, Ponta Grossa, v.1, n.2, p.18-24. 2001. Available from: https://www. alice.cnptia.embrapa.br/alice/bitstream/doc/512901/1/ SASMAGRI.pdf. Access on: 13 Jun. 2018.

COMPANHIA NACIONAL DE ABASTECIMENTO (CONAB). Acompanhamento da safra brasileira de cana: Terceiro levantamento. Brasília: CONAB, 2016. Available from: https://www.conab.gov. $\mathrm{br}$ /info-agro/safras/cana/boletim-da-safra-de-cana-de-acucar/ item/download/1206_f59b2b99058a 19b94e2838d4fce 147fd. Access on: 22 Dec. 2018.

Conselho dos Produtores de Cana-de-Açúcar, Açúcar e Álcool do Estado de São Paulo (CONSECANA). Manual de instruções. Piracicaba: CONSECANA-SP, 2006. p. 1 12. Available from: http://oricana.com. br/novosite/manual_consecana.pdf. Access on: 13 Jun. 2018.

Conselho dos Produtores de Cana-de-Açúcar, Açúcar e Álcool do Estado de São Paulo (CONSECANA).Dados históricos: Preço do $\mathrm{kg}$ do ATR. Piracicaba: CONSECANA-SP, 2017. Available from: https://www.consecana.com.br/login.asp?url=preco_mensal. asp. Access on: 27 Jan. 2017.

CRUZ, I. A broca da cana-de-açúcar, Diatraea saccharalis, em milho, no Brasil. Circular Técnica 90. Sete Lagoas: Embrapa Milho e Sorgo, 2007. Available from: https://www.infoteca.cnptia.embrapa.br/infoteca/ bitstream/doc/47671 1/1/Circ90.pdf. Access on: 28 Aug. 2016.
DINARDO-MIRANDA, L.L. Pragas. In: DINARDO-MIRANDA, L.L.; VASCONCELOS, A.C.M.; LANDELL, M.G.A. (orgs). Cana-de-açúcar. Campinas: Instituto Agronômico, 2008. p.349-404.

DINARDO-MIRANDA, L.L.; FRACASSO, J.V.; COSTA, V.P.; ANJOS, I.A.; LOPES, D.O.P. Reação de cultivares de cana-de-açúcar à broca do colmo. Bragantia, Campinas, v.72, n. 1, p.29-34, 2013. https://doi.org/10.1590/S0006-87052013005000012

ERLER, G. Controle da broca da cana-de-açúcar Diatraea saccharalis (Fabricius, 1794) (Lepidoptera: Crambidae) através de isca tóxica. 2010. Dissertation (Master in Entomology) - Universidade de São Paulo, Piracicaba, 2010. Available from: https://www.teses. usp.br/teses/disponiveis/1 1/11 146/tde-26112010-144048/ publico/Greice_Erler.pdf. Access on: 13 Jun. 2018.

GALLO, D. et al. Entomologia agrícola. Piracicaba: FEALQ, 2002. 920p.

IRAC. Comitê de ação à resistência a Inseticidas. Mogi Mirim: IRAC 2017. Available from: https://www.irac-br.org/modo-de-acao/. Access on: 30 Oct. 2017.

JAMES, G. Sugarcane. Oxford: Blackwell, 2004. 216p. https:// doi.org/10.1002/9780470995358

LOPES, D.O.P. Comportamento de genótipos de cana-de-açúcar em relação ao complexo broca-podridão causado pela ação de Diatraea saccharalis (FABRICIUS, 1794) (Lepidoptera: Crambidae) e microorganismos. 2012. Dissertation (Master in Entomology) Universidade Estadual Paulista, Jaboticabal, 2012. Available from: https://repositorio.unesp.br/bitstream/handle/1 1449/91331/ lopes_dop_me_jabo.pdf?sequence=1. Access on: 28 Oct. 2017.

MARIN, F.; NASSIF, D.S.P. Mudanças climáticas e a cana-deaçúcar no Brasil: Fisiologia, conjuntura e cenário futuro. Revista Brasileira de Engenharia Agrícola e Ambiental, Campina Grande, v.17, n.2, p.232-239, 2013. https://doi.org/10.1590/ S1415-43662013000200015

PINTO, A.S. (org.). Controle de pragas da cana-de-açúcar. Sertãozinho: Biocontrol, 2006. 64p.

PINTO, A.S.; CANO, M.A.V.; SANTOS, E.M. A broca-da-cana, Diatraea saccharalis. In: PINTO, A.S. (org). Controle de pragas da cana-de-açúcar. Sertãozinho: Biocontrol, 2006. p.15-20.

União da Agroindústria Canavieira de São Paulo (UNICA). Cana-deaçúcar: Perfil da Produção. Available from: https://unica.com.br/ setor-sucroenergetico/historico-do-setor/. Access on: 27 Jan. 2017.

PORTELA, G.L.F.; PÁDUA, L.E.M.; BRANCO, R.T.P.C.; BARBOSA, O.A.; SILVA, P.R.R. Flutuação populacional de Diatraea saccharalis (Fabricius, 1794) (Lepidoptera - Crambidae) em cana-de-açúcar no município de União-PI. Revista Brasileira de Ciências Agrárias, Recife, v.5, n.3, p.303-307, 2010. https://doi.org/10.5039/agraria.v5i3a510

SANDOVAL, S.S.; SENÔ, K.C.A. Comportamento e controle da Diatraea saccharalis na cultura da cana-de-açúcar. Nucleus, Ituverava, v.7, n. 1, p.243-258, 2010. https://doi.org/10.3738/1982.2278-311

SEGATO, S.V.; PINTO, A.S.; JENDIROBA, E.; NÓBREGA, J.C.M. (org.). Atualização em produção de cana-de-açúcar. Piracicaba: Livroceres, 2006. 415p.

(C) 2020 Instituto Biológico

This is an open access article distributed under the terms of the Creative Commons license. 